\title{
Testing the Extensional Detachment Paradigm: A Borehole Observatory in the Sevier Desert Basin
}

\author{
by Nicholas Christie-Blick, Mark H. Anders, Gianreto Manatschal, \\ and Brian P. Wernicke
}

doi:10.2204/iodp.sd.8.09.2009

Low-angle normal faults or detachments are widely regarded as playing an important role in crustal extension and the development of rifted continental margins (Manatschal et al., 2007). However, no consensus exists on how to resolve the mechanical paradox implied by the gentle dips of these faults and by the general absence of evidence for associated seismicity (Sibson, 1985; Wernicke, 1995; Axen, 2004). As part of a new initiative to rationalize geological and geophysical evidence and our theoretical understanding of how rocks deform, a group of forty-seven scientists and drilling experts from five countries met for four days on 15-18 July 2008 to discuss the present status of the paradox and a borehole-based strategy for resolving it. The workshop was held at two venues in Utah (the Utah Department of Natural Resources in Salt Lake City, and Solitude Mountain Resort in the adjacent Wasatch Range), with a one-day field trip to the Sevier Desert basin of west-central Utah (Figs. 1,2) to examine the general setting of potential drill sites and the footwall geology of the Sevier Desert detachment (Canyon Range).

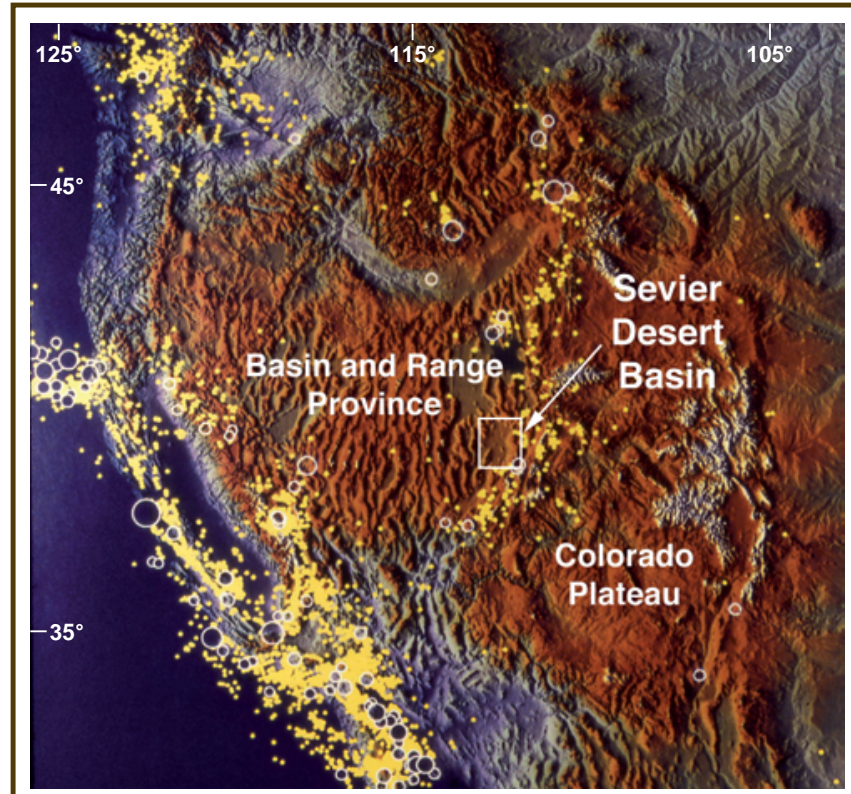

Figure 1. Regional physiography, seismicity, and location of the Sevier Desert basin in the western United States (from Simpson and Anders, 1992). White open circles are earthquakes greater than magnitude 6.0 from 1900 to 1975. Yellow dots are earthquakes greater than magnitude 2.5, occurring between 1970 and 1985. The north-trending band of seismicity adjacent to the Sevier Desert marks the eastern edge of the Basin and Range Province. Intense seismicity to the west and southwest, and including the western Basin and Range Province, corresponds with the diffuse transform plate boundary of which the San Andreas fault system is the most important element.
Interest in the Sevier Desert detachment (Fig. 3) relates to its large scale, geometric simplicity, severe misorientation with respect to $\sigma_{1}$, comparatively shallow depth, and compelling evidence for contemporary slip, as well as its accessibility from more or less flat public land (Von Tish et al., 1985; Niemi et al., 2004; Wills et al., 2005). The fault was first recognized in the mid-1970s, on the basis of seismic reflection data and commercial wells, as the subsurface contact between Paleozoic carbonate rocks and Cenozoic basin fill (McDonald, 1976). It is thought by most workers to root into the crust to the west of the Sevier Desert, to have large offset (as much as $47 \mathrm{~km}$; DeCelles and Coogan, 2006), and to have been active since the late Oligocene at or near its present dip of $11^{\circ}$ (GPS data and prominent Holocene scarps on steeply inclined hanging-wall faults that appear to sole downward into the detachment; Von Tish et al., 1985; Oviatt, 1989; Wernicke, 1995; Niemi et al., 2004). Whether the detachment fault crops out today at the eastern margin of the Sevier Desert basin is unresolved (Otton, 1995; Wills and Anders, 1999). No modern scarps have been observed there. Although no historic seismicity has been documented on the detachment, its scale is consistent with earthquake magnitudes at least as large as $\mathrm{Mw}=7.0$ (Wernicke, 1995). It is also possible that slip is currently taking place by aseismic creep. While dozens of low-angle normal faults have been recognized, at numerous locations in both extensional and orogenic settings - and by low angle we refer to the dip of a fault today, not necessarily its dip when it was active-the Sevier Desert detachment is one of very few that is sufficiently well-documented, active, and accessible from the surface that it might reasonably yield new insights about the conditions under which such faults slip.

A two-step drilling strategy emerged during workshop discussions. The first step (a pilot hole) is to re-enter one of several wells drilled by petroleum companies in the Sevier Desert basin (Wills et al., 2005), to deviate a few tens of meters above the base of the Cenozoic section, and to core through the detachment level to at least several tens of meters below the top of the Paleozoic section. Before embarking on a dedicated main hole, it is imperative to demonstrate that a fault is present (i.e., that fault rocks are present). The detachment interpretation, though generally accepted, currently depends entirely on geophysical data, not direct observation. It may be necessary to deviate and core through the detachment more than once to obtain definitive samples. The well provisionally selected for the 
pilot hole, and for technical as well as geological reasons, is ARCO Hole-in-Rock in the southern Sevier Desert (AHR in Figs. 2, 3B). The detachment is sufficiently deep at the Hole-in-Rock well $(2774 \mathrm{~m})$, and its hanging-wall offset is sufficiently large that fault rocks ought to be well-developed in both Cenozoic strata above and Paleozoic strata below. At the same time, the existence of late Pleistocene to Holocene fault scarps to the east of the well is consistent with recent displacement on the detachment at this location.

The second step (main hole) is to core, log, and make in situ measurements at a location between a few tens of meters and $4 \mathrm{~km}$ west (downdip) of ARCO Hole-in-Rock, and intersecting the interpreted detachment at a depth of 2800-3500 m (Fig. 3B). All surface scarps appear to be east

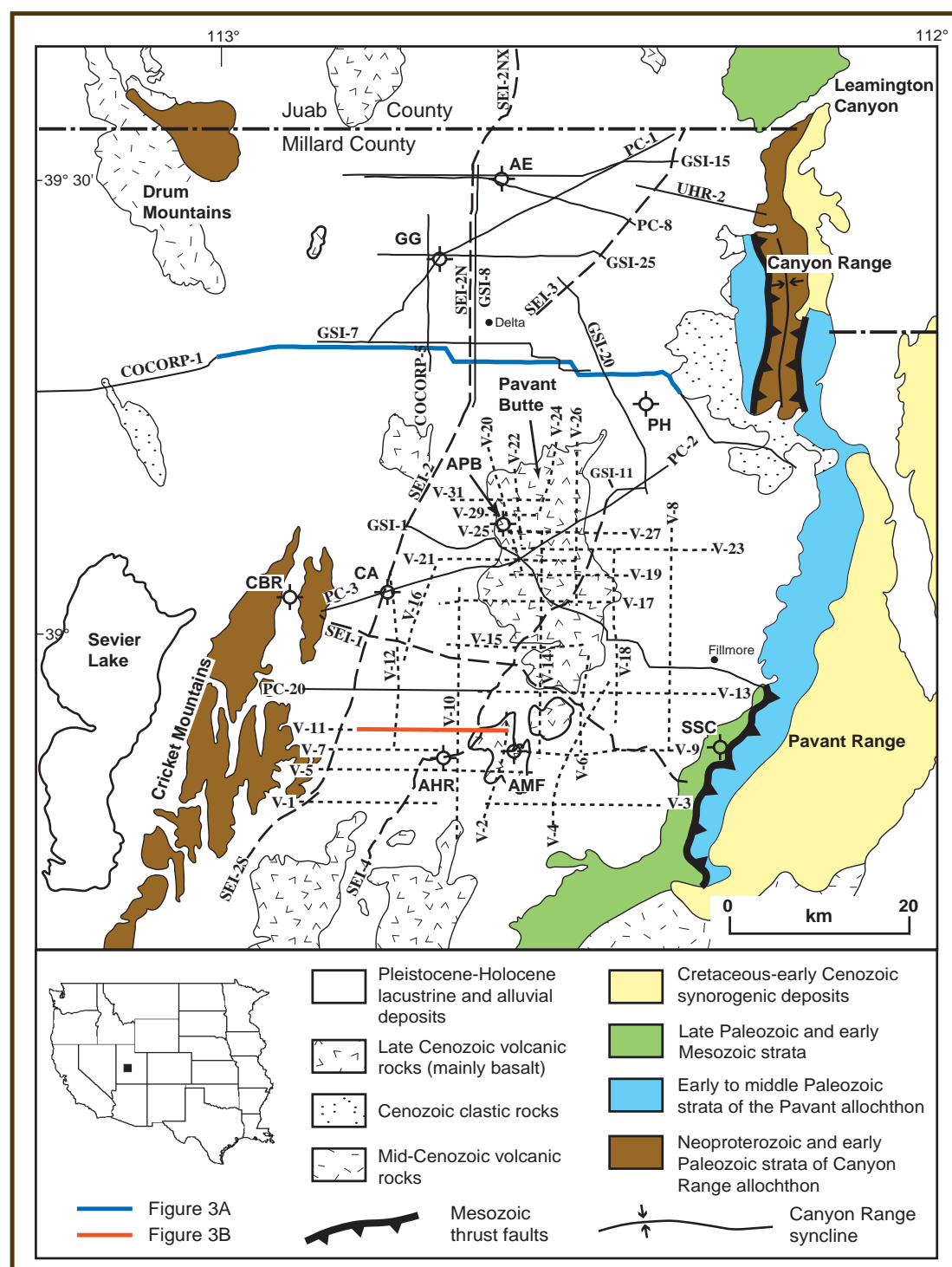

Figure 2. Generalized map of the Sevier Desert basin, west-central Utah, showing locations of wells and seismic reflection profiles (from Wills et al., 2005; see Fig. 1 for location). Wells: AE, Argonaut Energy Federal; AHR, ARCO Hole-in-Rock; AMF, ARCO Meadow Federal; APB, ARCO Pavant Butte; CA, Cominco American Federal; CBR, Chevron Black Rock; GG, Gulf Gronning; PH, Placid Henley; SSC, Shell Sunset Canyon. Solid, dashed, and dotted lines correspond with different seismic datasets. Part of Consortium for Continental Reflection Profiling (COCORP) Utah Line 1 (blue) is shown in Fig. 3A. A portion of Vastar Resources, Inc. Line V-11 (red) is shown in Fig. 3B. Thrust faults are the tightly folded Canyon Range thrust in the Canyon Range and the structurally lower Pavant thrust in the Pavant Range (teeth on upper plate). Inset map shows location relative to states in the western U.S. of the Hole-in-Rock well at this latitude. The selection of a site $4 \mathrm{~km}$ or more to the west of ARCO Hole-in-Rock would permit the detachment fault to be penetrated within Paleozoic or Neoproterozoic strata west of the intersection between the basin's western bounding fault and the detachment.

The principal objective of the second hole is to establish an observatory at a depth and location most likely to allow monitoring of the full rate of extension across the Sevier Desert ( 0.35 $\mathrm{mm} \mathrm{yr}^{-1}$; Niemi et al., 2004), and yet not so deep as to be prohibitively expensive. Among in situ measurements to be made in the vicinity of the detachment are the following: pore pressure, fracture permeability, fluid chemistry (including He), temperature, the orientation of stress axes, and the magnitude of differential stress. A borehole seismometer will be installed as part of a local array. A second objective of this main hole is to investigate the history of sediment accumulation and how the timing of basin development relates to exhumation of the detachment's footwall (based upon already published fission-track data for the Canyon Range; Stockli et al., 2001). A full suite of downhole logs (especially acoustic logging) will allow confident correlation with seismic reflection data. A byproduct of stratigraphic and geochronological analyses will be an extended lacustrine record of continental climate change since the late Oligocene.

A priority before any drilling is undertaken is to acquire new seismic reflection data in a grid encompassing both ARCO Hole-in-Rock and candidate locations for the proposed main hole. These data will be essential in establishing confidence in three-dimensional stratigraphic and structural geometry. Other pre-drill data that may be particularly useful-among many excellent ideas raised at the workshopare high-resolution seismic and GPR (ground-penetrating radar) data combined with trenching across prominent fault scarps, and the establishment of closely spaced GPS stations aimed at determining more precisely how contemporary extension is distributed across the Sevier Desert.

\section{Acknowledgments}

We thank ICDP for sponsoring the workshop, the Utah Geological Survey for logistical assistance, and all of the participants for stimulating discussions. 


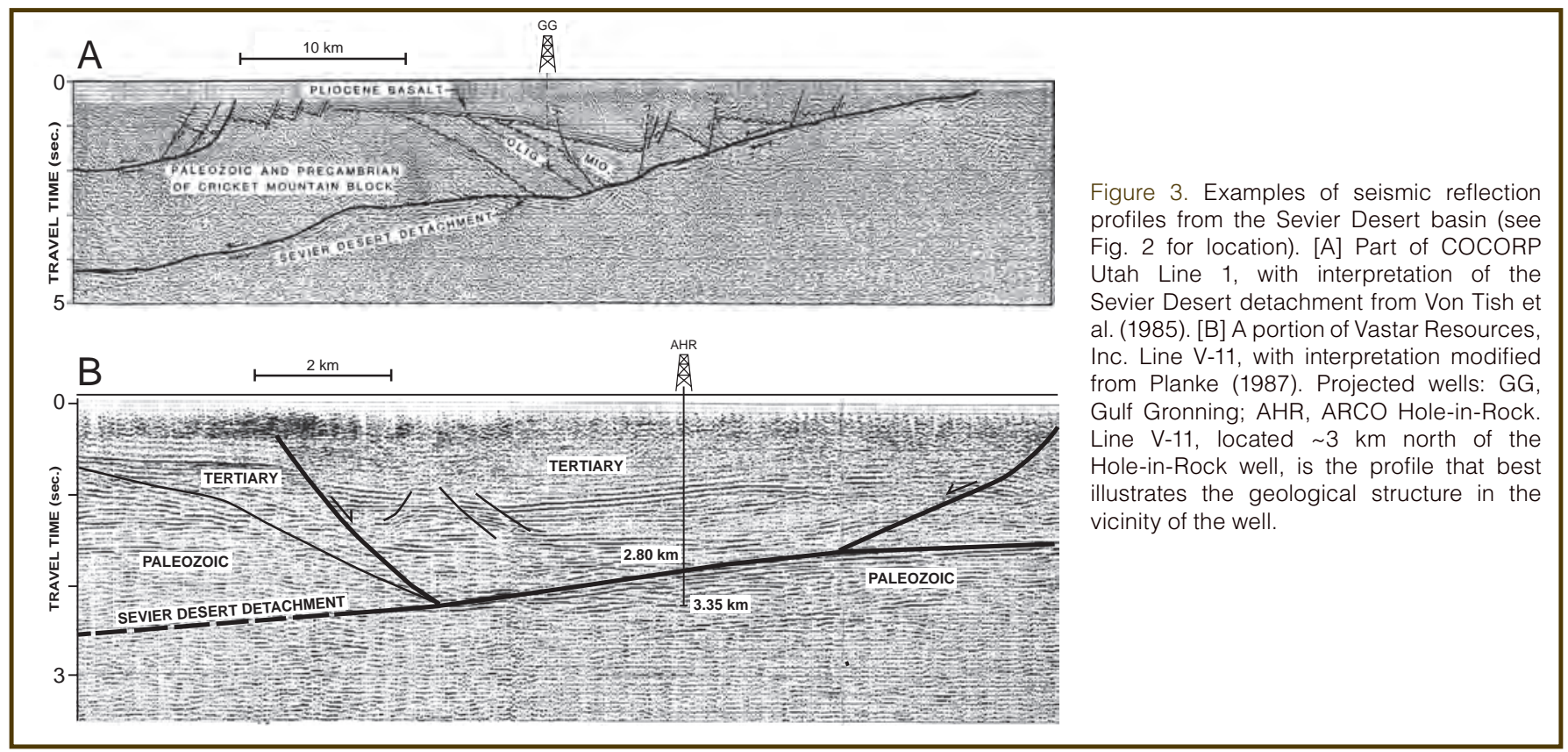

\section{References}

Axen, G.J., 2004. Mechanics of low-angle normal faults. In Karner, G.D., Taylor, B., and Driscoll, N.W. (Eds.), Rheology and Deformation of the Lithosphere at Continental Margins. New York (Columbia University Press), 46-91.

DeCelles, P.G., and Coogan, J.C., 2006. Regional structure and kinematic history of the Sevier fold and thrust belt, central Utah. Geol. Soc. Amer. Bull., 118:841-864, doi:10.1130/B25759.1.

Manatschal, G., Müntener, O., Lavier, L.L., Minshull, T.A., and PéronPinvidic, G., 2007. Observations from the Alpine Tethys and Iberia-Newfoundland margins pertinent to the interpretation of continental breakup. In Karner, G.D., Manatschal, G., and Pinheiro, L.M. (Eds.), Imaging, Mapping and Modelling Continental Lithosphere Extension and Breakup. London (Geological Society, Spec. Publ. 282), 291-324.

McDonald, R.E., 1976. Tertiary tectonics and sedimentary rocks along the transition: Basin and Range province to plateau and thrust belt province, Utah. In Hill, J.G. (Ed.), Symposium on Geology of the Cordilleran Hingeline. Denver, Colorado (Rocky Mountain Association of Geologists), 281-317.

Niemi, N.A., Wernicke, B.P., Friedrich, A.M., Simons, M., Bennett, R.A., and Davis, J.L., 2004. BARGEN continuous GPS data across the eastern Basin and Range province, and implications for fault system dynamics. Geophys. J. Int., 159:842-862, doi:10.1111/j.1365-246X.2004.02454.x.

Otton, J.K., 1995. Western frontal fault of the Canyon Range: Is it the breakaway zone of the Sevier Desert detachment? Geology, 23:547-550, doi:10.1130/0091-7613(1995)023<0547: WFFOTC $>2.3 . \mathrm{CO} ; 2$.

Oviatt, C.G., 1989. Quaternary Geology of Part of the Sevier Desert, Millard County, Utah. Utah Geological and Mineral Survey Special Studies 70, Salt Lake City, Utah (Utah Department of Natural Resources), $41 \mathrm{pp}$.

Planke, S., 1987. Cenozoic structures and evolution of the Sevier Desert basin, west-central Utah, from seismic reflection data. Master's thesis, University of Utah, Salt Lake City, Utah, $163 \mathrm{pp}$.
Sibson, R.H., 1985. A note on fault reactivation. J. Struct. Geol., 7:751-754, doi:10.1016/0191-8141(85)90150-6.

Simpson, D.W., and Anders, M.H., 1992. Tectonics and topography of the western U.S. - an example of digital map making. GSA Today, 2:118-121.

Stockli, D.F., Linn, J.K., Walker, J.D., and Dumitru, T.A., 2001. Miocene unroofing of the Canyon Range during extension along the Sevier Desert Detachment, west central Utah. Tectonics, 20:289-307, doi:10.1029/2000TC001237.

Von Tish, D.B., Allmendinger, R.W., and Sharp, J.W., 1985. History of Cenozoic extension in central Sevier Desert, west-central Utah, from COCORP seismic reflection data. AAPG Bull., 69:1077-1087.

Wernicke, B., 1995. Low-angle normal faults and seismicity: A review. J. Geophys. Res., 100:20159-20174, doi:10.1029/95JB01911.

Wills, S., and Anders, M.H., 1999. Tertiary normal faulting in the Canyon Range, eastern Sevier Desert. J. Geol., 107:659-682, doi:10.1086/314375.

Wills, S., Anders, M.H., and Christie-Blick, N., 2005. Pattern of Mesozoic thrust surfaces and Tertiary normal faults in the Sevier Desert subsurface, west-central Utah. Am. J. Sci., 305:42-100, doi:10.2475/ajs.305.1.42.

\section{Authors}

Nicholas Christie-Blick and Mark H. Anders, Department of Earth and Environmental Sciences and Lamont-Doherty Earth Observatory of Columbia University, Palisades, N.Y. 10964-8000, U.S.A., e-mail: ncb@1deo.columbia.edu.

Gianreto Manatschal, Université de Strasbourg, IPGSEOST, 1 rue Blessig F-67 084, France.

Brian P. Wernicke, Division of Geological and Planetary Sciences, California Institute of Technology, Pasadena, Calif. 91125, U.S.A.

\section{Web Link}

http://sevier.icdp-online.org/ 